\title{
PENGARUH DIGITAL MARKETING, WORD OF MOUTH, DAN KUALITAS PELAYANAN TERHADAP KEPUTUSAN PEMBELIAN
}

\author{
Gede Wisnu Saputra ${ }^{1}$ \\ I Gusti Agung Ketut Sri Ardani
}

${ }^{1,2}$ Fakultas Ekonomi dan Bisnis Universitas Udayana, Bali, Indonesia
email: gedewisnusaputra05@gmail.com

\begin{abstract}
ABSTRAK
Tujuan dari penelitian ini adalah untuk meganalisis pengaruh digital marketing, word of mouth, dan kualitas pelayanan terhadap keputusan pembelian. Penelitian ini dilakukan pada konsumen atau nasabah pengguna jasa PT. Pegadaian Kantor Wilayah VII Denpasar. Jumlah sampel dalam penelitian ini sebanyak 220 responden. Teknik pengambilan sampel yaitu accidental sampling. Pengumpulan data diperoleh dari hasil penyebaran kuesioner konsumen pengguna jasa PT. Pegadaian Kantor Wilayah VII Denpasar. Analisis data dalam penelitian ini menggunakan analisis regresi linear berganda. Hasil analisi regresi linear berganda menunjukan bahwa variabel digital marketing, word of mouth, dan kualitas pelayanan berpengaruh positif dan signifikkan terhadap keputusan pembelian. Hasil penelitian ini menunjukan bahwa semakin tinggi digital marketing, word of mouth, dan kualitas pelayanan maka akan meningkatkan keputusan pembelian.
\end{abstract}

Kata kunci: digital marketing, word of mouth, kualitas pelayanan, keputusan pembelian

\begin{abstract}
The purpose of this study is to analyze the effect of digital marketing, word of mouth, and service quality on purchasing decisions. This research was conducted on consumers or customers of PT. Pegadaian Regional Office VII Denpasar. The number of samples in this study were 220 respondents. The sampling technique is accidental sampling. Data collection was obtained from the results of the distribution of consumer questionnaires PT. Pegadaian Regional Office VII Denpasar. Data analysis in this study uses multiple linear regression analysis. The results of multiple linear regression analysis show that digital marketing, word of mouth, and service quality variables have a positive and significant effect on purchasing decisions. The results of this study indicate that the higher the digital marketing, word of mouth, and quality of service, it will increase purchasing decisions.

Keywords: digital marketing, word of mouth, service quality, purchasing decisions
\end{abstract}




\section{PENDAHULUAN}

Perkembangan teknologi membuat konsumen memanfaatkan teknologi untuk memenuhi kebutuhan sehari-hari. Hal ini dapat dilihat dari seberapa banyak konsumen menggunakan fasilitas teknologi informasi dalam memenuhi informasi yang dibutuhkannya, salah satunya yaitu penggunaan internet. Internet berkembang pesat dan menjadi salah satu sumber informasi yang dapat diakses dengan mudah yang mengakibatkan arus perubahan konsumen dalam memenuhi gaya hidup.

Arus perubahan zaman membawa gaya hidup belanja masyarakat bergeser dari yang sifatnya konvensional menuju pada transaksi situs penjualan online yang terpengaruhi dari arus perubahan gaya hidup masyarakat tersebut. Arus perubahahan gaya belanja masyarakat mengakibatkan banyak situs penjualan online yang mengakibatkan masyarakat mendapatkan informasi lebih dan bertransaksi dengan mudah tanpa harus pergi ke tempat penjualan barang atau jasa tersebut. Perubahan perilaku konsumen tersebut disebabkan manfaat dari pada pembelian online yang lebih praktis dan efesien waktu, tenaga maupun biaya.

Seiring berkembangnya bisnis saat ini, tantangan dan persaingan semakin tajam dalam merebut pangsa pasar, perusahaan dituntut untuk dapat memberdayakan sumber daya yang dimiliki secara efektif dan efisien agar perusahaan bisa mempunyai keunggulan bersaing. Setiap organisasi perusahaan diharapkan dapat menyusun suatu strategi pemasaran agar tetap bertahan dalam menghadapi persaingan, salah satunya adalah mempunyai strategi pemasaran berupa bauran pemasaran dengan digital marketing. Strategi bisnis perusahaan ini diharapkan dapat memberikan dampak pada keuntungan keuangan, non keungan, bertahan di dalam industri, dan guna mencapai tujuan jangka panjang organisasi (Dewi, 2017).

Digital marketing adalah salah satu media pemasaran yang saat ini sedang banyak diminati oleh masyarakat untuk medukung berbagai kegiatan yang dilakukan. Mereka sedikit demi sedikit mulai meninggalkan model pemasaran konvesional/tradisional beralih ke pemasaran modern yaitu digital marketing. Digital marketing komunikasi dan transaksi dapat dilakukan setiap waktu dalam pemasaran digital. Survei yang dilakukan oleh Pradani (2017) menemukan bahwa 132,7 juta penduduk Indonesia telah terhubung ke internet, dimana saat ini internet memegang peran penting dalam penentuan keputusan pembelian konsumen.

Peningkatan jumlah pengguna internet dan media sosial menjadi peluang yang sangat besar bagi para pelaku bisnis untuk memasarkan produk-produknya. Hayden dan Herman dalam Hermawan (2012) menggunakan istilah red-hot, untuk menggambarkan peluang pemasar yang sedemikian besar dalam pemasaran melalui internet. Internet pemasaran produk dapat lebih terbantu, karena internet memungkinkan proses pemasaran yang lebih efektif, respon yang lebih cepat dan biaya yang lebih murah (Hermawan, 2012). Biaya yang murah dan penyebaran informasi yang cepat diharapkan dapat meningkatkan penjualan sehingga dapat mencapai omzet yang sesuai target.

Pemasar digital juga dapat mengetahui respon konsumen terhadap produk yang ditawarkan dengan melihat testimoni atau komentar yang diposting. Komunikasi yang baik dapat mempererat hubungan baik dengan konsumen. Hal tersebut secara tidak langsung akan menjadi kepuasan tersendiri bagi konsumen 
karena konsumen merasa diperhatikan. Ketika konsumen mendapat kepuasan, maka konsumen akan memberikan testimoni yang positif kemudian akan merekomendasikan kepada orang lain.

Rekomendasi dapat dilakukan melalui media sosial atau dari Word Of Mouth. Komunikasi Word of Mouth adalah dimana para individu saling menukar informasi, khususnya tentang hal-hal yang bagus sehingga dapat mempengaruhi keputusan konsumen dan akan membuat bisnis mencapai sukses (J. Supranto dan Nanda L, 2011). Pernyataan tersebut senada dengan penelitian yang dilakukan Onbee Marketing Research bekerjasama dengan Majalah SWA (2009) membuktikan bahwa tingkat WOM Conversation sebesar $85 \%$ dan menjadikan WOM sebagai sumber informasi untuk mengubah keputusannya sebesar $67 \%$. Efek dari adanya WOM ini sangat besar, bahkan banyak pemasar yang telah memanfaatkannya karena berasal dari sumber terpercaya. Perusahaan diharapkan mampu memberikan pelayanan yang baik dalam memberikan feed back disetiap komentar postingan agar konsumen merasa dilayani dengan baik.

Pada pembuatan keputuasan pembelian, kualitas dari pelayanan adalah hal yang penting untuk dipertimbangkan. Kualitas pelayanan yang diberikan oleh perusahaan, yaitu bertujuan untuk memberikan kemudahan bagi konsumen. Setiap menjalankan proses bisnis baik barang maupun jasa, konsumen harus diberikan pelayanan yang baik karena kualitas pelayanan memiliki hubungan yang erat dengan keputusan pembelian. Perusahaan dapat mempertahankan usahanya dan mampu bersaing dengan pesaing lainnya apabila memberikan pelayanan yang baik (Permatasari, 2017). Pelayanan konsumen yang baik dan memuaskan harus menjadi misi utama di sektor jasa dimana kepuasan konsumen menjadi utama.

PT. Pegadaian Kantor Wilayah VII Denpasar adalah sebuah perusahaan BUMN sektor keuangan Indonesia yang bergerak pada tiga lini bisnis perusahaan yaitu pembiayaan, emas dan aneka jasa. Pegadaian menawarkan pembiayaan yang tercepat, termudah, aman dan selalu memberikan pembinaan terhadap usaha golongan menengah kebawah untuk mendorong pertumbuhan ekonomi. Dalam menjalankan usahanya Pegadaian memastikan pemerataan pelayanan dan infrastruktur yang memberikan kemudahan dan kenyamanan bagi masyarakat. PT. Pegadaian Kantor Wilayah VII Denpasar membawahi seluruh kantor cabang Pegadaian yang ada di Bali, NTT, dan NTB.

Dalam rangka menganalisis perkembangan jumlah nasabah, dilakukan observasi nilai Out Standing Loan nasabah PT. Pegadaian (Persero) Kantor Wilayah VII Denpasar, dari bulan Januari hingga bulan November 2018. Adapun data yang didapatkan adalah pada Tabel 1 .

Berdasarkan Tabel 1. di bawah fluktuasi data OSL (Out Standing Loan) atau Kredit aktif masyarakat di PT. Pegadaian (Persero) Kantor Wilayah VII Denpasar tahun 2018 mengalami peningkatan dan penurunan. Nilai tertinggi terjadi pada bulan April 2018 dengan Rp. 3.943.643.000 dan nilai terendah terjadi pada bulan Januari 2018 dengan Rp. 3.659.206.000. Oleh karena itu, PT. Pegadaian (Persero) Kantor Wilayah VII Denpasar harus lebih meningkatkan kualitas pelayanan agar nilai kredit aktif setiap bulannya dapat meningkat. Faktor yang menyebabkan peningkatan dan penurunan jumlah nilai kredit aktif antara lain karena banyaknya pesaing PT. Pegadaian yang menawarkan fitur jasa serupa dan menawarkan fitur 
lain yang tidak kalah menarik sehingga nasabah mempunyai banyak pilihan tempat untuk bertransaksi.

Tabel 1.

Nilai OSL (Out Standing Loan) PT. Pegadaian (Persero) Kantor Wilayah VII Denpasar Tahun 2018

\begin{tabular}{clc}
\hline No & \multicolumn{1}{c}{ Bulan } & Nilai Rupiah \\
\hline 1 & Januari & 3.659 .206 .000 \\
2 & Februari & 3.786 .665 .000 \\
3 & Maret & 3.868 .401 .000 \\
4 & April & 3.943 .643 .000 \\
5 & Mei & 3.940 .872 .000 \\
6 & Juni & 3.894 .121 .000 \\
7 & Juli & 3.931 .681 .000 \\
8 & Agustus & 3.917 .708 .000 \\
9 & September & 3.891 .413 .000 \\
10 & Oktober & 3.876 .854 .000 \\
11 & November & 3.921 .835 .000 \\
& Total & $\mathbf{4 2 . 6 3 2 . 3 9 9 . 0 0 0}$ \\
& Rata-Rata & $\mathbf{3 . 8 7 5 . 6 7 3 . 0 0 0}$
\end{tabular}

Sumber: PT. Pegadaian (Persero) Kantor Wilayah VII Denpasar, 2018

Berdasarkan latar belakang di atas maka penelitian ini memiliki tujuan untuk mengetahui Pengaruh Digital marketing, Word Of Mouth dan Kualitas Pelayanan Terhadap Keputusan Pembelian.

Tujuan penelitian ini adalah: (1) menganalisis pengaruh digital marketing terhadap keputusan pembelian, (2) menganalisis pengaruh word of mouth terhadap keputusan pembelian, dan (3) menganalisis pengaruh kualitas pelayanan terhadap keputusan pembelian.

Salah satu teori yang mendukung penelitian ini yaitu teori pemasaran. Pemasaran yang berhasil membutuhkan pengorganisasian dan perencanaan yang tepat, yaitu berupa suatu manajemen untuk mengorganisasikan dan merencanakan kegiatan pemasaran yang di sebut manajemen pemasaran. Berikut adalah beberapa definisi untuk mendapatkan pengertian pasti tentang manajemen pemasaran.

Kotler (2012:9) menyatakan bahwa manajemen pemasaran adalah proses perencanaan dan pelaksanaan pemikiran, penetapan harga, promosi serta penyaluran gagasan, barang, dan jasa untuk menciptakan pertukaran yang memenuhi sasaran-sasaran individu dan organisasi.

Pemasaran menurut William J Stanton dalam American marketing association jurnal (2016) pemasaran merupakan sebuah sistem keseluruhan dari beberapa kegiatan usaha yang mempunyai tujuan untuk menentukan harga, merencanakan, mendistribusikan barang atau jasa, dan mempromosikan barang atau jasa yang bisa memuaskan kebutuhan konsumen ataupun calon konsumen.

Adapun pengertian pemasaran menurut Downey (2002), pemasaran merupakan suatu proses dari penyusunan komunikasi yang efektif dan mempunyai tujuan untuk memberikan informasi seputar barang atau jasa yang dijual oleh pelaku usaha. Pemasaran berkaitian dengan bagaimana pelaku usaha bisa memuaskan kebutuhan dan keinginan masyarakat. 
Digital marketing adalah salah satu jenis kegiatan dalam pemasaran yang digunakan untuk mempromosikan atau memasarkan suatu produk atau jasa dan untuk menjangkau para calon konsumen dengan menggunakan media digital. Menurut Afrina (2015) Digital marketing adalah salah satu jenis pemasaran yang banyak digunakan untuk mempromosikan produk atau jasa dan untuk menjangkau konsumen menggunakan saluran digital. Di era globalisasi sangat penting menerapkan digital marketing karena cangkupan yang luas dan mudah digunakan.

Komunikasi Word of Mouth merupakan proses komunikasi yang berupa pemberian rekomendasi baik secara individu maupun kelompok terhadap suatu produk atau jasa yang bertujuan untuk memberikan informasi secara personal. Menurut Rangkuti (2010) Word Of Mouth adalah usaha memasarkan suatu produk atau jasa dengan menggunakan virus marketing sehingga pelanggan membicarakan, mempromosikan, dan merekomendasikan suatu produk dan jasa kepada orang lain secara antusias dan sukarela. Teknik ini sangat baik digunakan karena konsumen sebelum membeli barang dia akan mencari rekomendasi dari teman, kerabat atau keluarga terhadap pembelian produk.

Kualitas pelayanan adalah tingkat keunggulan yang diharapkan dan pengendalian atas tingkat keunggulan tersebut untuk memenuhi keinginan pelanggan. Menurut Lovelock ( 2011), kualitas jasa merupakan tingkat keunggulan (excellence) yang diharapkan dan pengendalian atas keunggulan tersebut untuk memenuhi keinginan pelanggan. Terdapat dua faktor utama yang memengaruhi kualitas jasa: jasa yang diharapkan (expected service) dan jasa yang di persepsikan. Implikasinya, baik buruknya kualitas pelayanan tergantung pada kemampuan penyedia jasa memenuhi harapan pelanggan secara konsisten.

Menurut Prasetya (2015) dalam penelitiannya pada pengaruh kegiatan digital marketing dan perilaku online konsumen pada peningkatan kesadaran konsumen dan dampaknya terhadap keputusan pembelian menemukan bahwa digital marketing berpengaruh positif terhadap keputusan pembelian.

Penelitian yang dilakukan oleh Daria dan Setyorini (2017) menganalisi pengaruh strategi e-marketing mix kepada keputusan membeli pada toko online studi pada konsumen zalora.co.id Bandung. Hasil Secara parsial yang berpengaruh positif dan signifikan yaitu kemudahan penggunaan. Sedangkan yang berpengaruh negatif dan signifikan yaitu harga, produk, dan atmosfer website. Variabel yang tidak memiliki pengaruh yaitu kepercayaan dan promosi.

Penelitian yang dilakukan oleh Fransilia (2019) meneliti tentang pengaruh digital marketing terhadap keputusan pembelian pada Matahari Departmen Store Manado Town Square. Hasil penelitian menunjukan bahwa hasil dari analisis regresi linear sederhana maka diperoleh nilai koefisien regresi yang positif, sehingga dapat dikatakan bahwa arah pengaruh variabel E-Commerce terhadap variabel keputusan pembelian yaitu positif. Berdasarkan penelitian tersebut, rumusan hipotesis yang digunakan yaitu:

$\mathrm{H}_{1}$ : Digital marketing berpengaruh positif dan signifikan terhadap keputusan pembelian.

Kurnia (2015) melakukan penelitian dengan hasil bahwa komunikasi Word Of Mouth berpengaruh signifikan terhadap keputusan pembelian. Hal ini sejalan dengan penelitian yang dilakukan oleh Ibrahim \& Yuliati (2017) di Waroeng Steak 
and Shake Bandung yang menemukan bawha Word Of Mouth berpengaruh secara positif dan signifikan terhadap keputusan pembelian konsumen.

Penelitian yang dilakukan oleh Rachman dan Totok (2016) meneliti tentang komunikasi word of mouth dan keputusan pembelian batik di Bangkalan. Hasil penelitian menyebutkan bahwa Faktor-faktor yang paling berpengaruh terhadap keputusan pembelian Batik Bangkalan adalah kesadaran merek dan resepsi masyarakat. Sedangkan faktor yang tidak berpengaruh terhadap keputusan pembelian adalah komunikasi word of mouth. Tidak berpengaruhnya komunikasi word of mouth terhadap keputusan pembelian Batik Bangkalan dikarenakan indikator yang digunakan variabel X1 hanya sebatas pada membicarakan, mempromosikan, dan merekomendasikan dan tidak sampai pada tahap mempersuasif, mengajak, dan mendorong masyarakat untuk membeli batik Bangkalan.

Penelitian yang dilakukan oleh Rahmi (2017) meneliti tentang pengaruh Word Of Mouth Communication terhadap keputusan pembelian konsumen pada Boardgame Lounge Smart Cafe Pekanbaru. Hasil penelitian menunjukan bahwa terdapat pengaruh antara word of mouth communication terhadap keputusan pembelian konsumen pada Boardgame lounge smart cafe. Berdasarkan penelitian tersebut, rumusan hipotesis yang digunakan yaitu:

$\mathrm{H}_{2}$ : Word Of Mouth berpengaruh positif dan signifikan terhadap keputusan pembelian.

Arifin (2017) dalam penelitiannya memiliki hasil bahwa kualitas pelayanan berpengaruh positif dan signifikan terhadap keputusan pembelian konsumen. Hal ini sejalan dengan penelitian Amrullah (2016) menemukan hubungan yang positif dan signifikan secara parsial antara variabel Kualitas Pelayanan dan variabel Keputusan Pembelian yang mengandung makna bahwa semakin tinggi kualitas pelayanan yang diberikan, maka konsumen cenderung untuk melakukan pembelian di perusahaan tersebut.

Penelitian yang dilakukan oleh Febriano et al. (2018) meneliti tentang Analysis Of The Influencer Of Price, Promotion, Location And Service Quality On Purchase Decision In PT. Indomaret Manado Unit Jalan Sea. Hasil penelitian menunjukan bahwa Promosi berpengaruh positif dan tidak signifikan sedangkan Kualitas pelayanan berpengaruh negative dan tidak signifikan terhadap keputusan pembelian konsumen. Harga, Promosi, Lokasi dan Kualitas Pelayanan secara simultan berpengaruh signifikan terhadap keputusan pembelian konsumen. PT. Indomaret Manado Unit Jalan Sea sebaiknya lebih meningkatkan strategi pemasaran dalam Harga, Promosi, Lokasi serta Kualitas Pelayanan untuk meningkatkan keputusan pembelian.

$\mathrm{H}_{1}$ : Kualitas Pelayanan berpengaruh positif dan signifikan terhadap keputusan pembelian.

\section{METODE PENELITIAN}

Desain penelitian ini menggunakan desain deskriptif yang bertujuan untuk menggambarkan sifat sesuatu yang tengah berlangsung pada saat riset dilakukan dan memeriksa sebab-sebab dari suatu gejala tertentu dengan menyebarkan 
kuisioner dengan menggunakan metode accidental sampling. Penelitian kali ini dirancang untuk mengetahui bagaimana hubungan antara pengaruh digital marketing, Word Of Mouth dan kualitas pelayanan terhadap keputusan pembelian konsumen dengan menggunakan metode pendekatan kuantitatif. Variabel-variabel dalam penelitian ini terdiri dari variabel independen dan variabel dependen. Variabel-variabel yang diteliti diantaranya digital marketing (X1), Word Of Mouth (X2), kualitas pelayanan (X3) dan keputusan pembelian konsumen (Y).

Penelitian ini dilaksanakan di PT. Pegadaian Kantor Wilayah VII Denpasar yang beralamat di Jl. Raya Puputan No.23.C, Renon, Denpasar Selatan.

Jenis data yang digunakan dalam penelitian ini adalah data kuantitatif dalam penelitian ini meliputi data yang berhubungan dengan permasalahan di PT. Pegadaian (Persero) Denpasar dan data kualitatif yang digunakan dalam penelitian ini adalah gambaran umum mengenai digital marketing, Word Of Mouth dan kualitas pelayanan terhadap keputusan pembelian konsumen. Sumber data dalam penelitian adalah data primer meliputi respon konsumen terhadap digital marketing, Word Of Mouth, kualitas pelayanan dan keputusan pembelian yang diperoleh dari hasil penyebaran kuisioner, dan data sekunder seperti sejarah berdirinya PT. Pegadaian Denpasar, struktur organisasi, serta deskripsi jabatan dan kajian empiris yaitu penelitian sebelumnya yang ada kaitannya dengan penelitian penulis yang akan disusun.

Populasi dari penelitian ini adalah pelanggan pengguna jasa Pegadaian Kantor wilayah Denpasar. Teknik penentuan sampel pada penelitian adalah metode accidental sampling, yaitu teknik penentuan sampel berdasarkan kebetulan, yaitu siapa saja yang secara kebetulan bertemu dengan peneliti dapat digunakan sebagai sampel, bila orang yang kebetulan ditemui dipandang cocok sebagai sumber data dan memenuhi kriteria sebagai responden (Sugiyono, 2014:122). Ukuran sampel yang digunakan dalam penelitian ini yaitu sebanyak 220 orang. Metode pengumpulan data yang digunakan dalam penelitian ini kuesioner, yaitu teknik pengumpulan data yang dilakukan dengan cara memberi seperangkat pernyataan tertulis kepada responden untuk dijawab (Sugiyono, 2014:199). Dokumentasi, merupakan catatan peristiwa yang sudah berlalu (Sugiyono, 2014:422). Data yang diperoleh dari hasil dokumentasi berupa data kunjungan nasabah ke Pegadaian Kantor Wilayah VII Denpasar. Pada penelitian ini, kuesioner disebarkan kepada pelanggan pengguna jasa Pegadaian Kantor wilayah Denpasar.

\section{HASIL DAN PEMBAHASAN}

Uji validitas dilakukan dengan mengkorelasikan antara skor faktor dengan skor total dan bila korelasi tiap faktor tersebut bernilai positif ( $\mathrm{r}>0,3)$, maka instrumen penelitian tersebut dapat dikatakan valid. Instrumen yang valid adalah instrumen yang dapat digunakan untuk mengukur apa yang seharusnya diukur. Tinggi rendahnya validitas menunjukkan sejauh mana data yang terkumpul tidak menyimpang dari gambaran tentang variabel yang dimaksud. Hasil uji validitas penelitian ini ditunjukkan dalam Tabel 2 berikut ini: 
Tabel 2.

Hasil Uji Validitas

\begin{tabular}{|c|c|c|c|c|}
\hline No & Variabel & $\begin{array}{c}\text { Item } \\
\text { Pernyataan }\end{array}$ & $\begin{array}{c}\text { Korelasi Item } \\
\text { Total }\end{array}$ & Keterangan \\
\hline \multirow{8}{*}{1} & \multirow{7}{*}{ Digital Marketing } & $\mathrm{X} 1.1$ & 0,822 & Valid \\
\hline & & $\mathrm{X} 1.2$ & 0,915 & Valid \\
\hline & & X1.3 & 0,906 & Valid \\
\hline & & X1.4 & 0,909 & Valid \\
\hline & & X1.5 & 0,903 & Valid \\
\hline & & X1.6 & 0,935 & Valid \\
\hline & & X1.7 & 0,921 & Valid \\
\hline & \multirow{5}{*}{ Word of Mouth } & X1.8 & 0,613 & Valid \\
\hline \multirow{4}{*}{2} & & X2.1 & 0,967 & Valid \\
\hline & & $\mathrm{X} 2.2$ & 0,974 & Valid \\
\hline & & X2.3 & 0,948 & Valid \\
\hline & & X3.1 & 0,908 & Valid \\
\hline \multirow{2}{*}{3} & \multirow{3}{*}{ Kualitas Pelayanan } & X 3.2 & 0,912 & Valid \\
\hline & & X3.3 & 0,911 & Valid \\
\hline \multirow{8}{*}{4} & & X 3.4 & 0,894 & Valid \\
\hline & \multirow{7}{*}{ Keputusan Pembelian } & X3.5 & 0,896 & Valid \\
\hline & & Y1.1 & 0,896 & Valid \\
\hline & & Y1.2 & 0,934 & Valid \\
\hline & & Y1.3 & 0,960 & Valid \\
\hline & & Y1.4 & 0,940 & Valid \\
\hline & & Y1.5 & 0,951 & Valid \\
\hline & & Y1.6 & 0,814 & Valid \\
\hline
\end{tabular}

Sumber: Data Primer, 2020

Tabel 2. menunjukkan bahwa seluruh koefisien korelasi dari indikator variabel yang diuji nilainya lebih besar dari 0,30 ( $\mathrm{r}>0,3)$. Hasil tersebut menunjukkan bahwa seluruh indikator yang terdapat pada penelitian ini terbukti valid.

Uji reliabilitas digunakan untuk mengukur konsistensi suatu variabel pada penelitian. Instrumen dikatakan reliabel bila memiliki nilai Cronbach Alpha > 0,60. Hasil uji reliabilitas penelitian ini ditunjukkan dalam Tabel 3 berikut ini:

Tabel 3

Hasil Reliabilitas

\begin{tabular}{lcc}
\hline \multicolumn{1}{c}{ Variabel } & Cronbad'sAlpha & Keterangan \\
\hline Digital Marketing (X1) & 0,952 & Reliabel \\
Word of Mouth (X2) & 0,960 & Reliabel \\
Kualitas Pelayanan (X3) & 0,943 & Reliabel \\
Keputusan Pembelian (Y) & 0,961 & Reliabel \\
\hline Sumber: Data Primer, 2020
\end{tabular}

Tabel 3. menunjukkan masing-masing nilai Cronbach's Alpha pada tiap instrumen tersebut lebih besar dari 0,6 (Cronbach's Alpha > 0,6). Hal tersebut menunjukkan bahwa semua instrumen reliabel sehingga dapat digunakan untuk melakukan penelitian.

Variabel keputusan pembelian pada penelitian ini merupakan variabel terikat. Variabel keputusan pembelian diukur dengan menggunakan 6 pernyataan yang 
ditanggapi menggunakan 5 poin Skala Likert. Hasil penelitian responden terhadap variabel keputusan pembelian dapat dilihat lebih rinci pada Tabel 4. berikut.

Tabel 4.

Deskripsi Jawaban Responden terhadap Keputusan Pembelian

\begin{tabular}{|c|c|c|c|c|c|c|c|c|c|}
\hline \multirow[t]{2}{*}{ No } & \multirow[t]{2}{*}{ Pernyataan } & \multicolumn{5}{|c|}{$\begin{array}{c}\text { Proporsi Jawaban } \\
\text { Responden } \\
\text { (orang) }\end{array}$} & \multirow[t]{2}{*}{ Jumlah } & \multirow[t]{2}{*}{$\begin{array}{l}\text { Rata- } \\
\text { Rata }\end{array}$} & \multirow[t]{2}{*}{ Kriteria } \\
\hline & & 1 & 2 & 3 & 4 & 5 & & & \\
\hline 1 & $\begin{array}{l}\text { Jika saya ingin } \\
\text { menggadaikan barang saya } \\
\text { pasti memilih jasa yang } \\
\text { ditawarkan Pegadaian } \\
\text { Kantor Wilayah VII } \\
\text { Denpasar }\end{array}$ & 51 & 8 & 24 & 102 & 35 & 722 & 3.28 & Cukup \\
\hline 2 & $\begin{array}{l}\text { Saya memilih jasa } \\
\text { Pegadaian Kantor Wilayah } \\
\text { VII Denpasar karena merasa } \\
\text { Aman }\end{array}$ & 39 & 0 & 44 & 110 & 27 & 746 & 3.39 & \multirow[b]{2}{*}{ Cukup } \\
\hline 3 & $\begin{array}{l}\text { Saya yakin menggunakan } \\
\text { jasa dari pegadaian Kantor } \\
\text { Wilayah VII Denpasar } \\
\text { merupakan keputusan yang } \\
\text { tepat }\end{array}$ & 41 & 2 & 56 & 86 & 35 & 732 & 3.33 & \\
\hline 4 & $\begin{array}{l}\text { Saya menggunakan jasa } \\
\text { yang ditawarkan Pegadaian } \\
\text { Kantor Wilayah VII } \\
\text { Denpasar }\end{array}$ & 37 & 2 & 46 & 111 & 24 & 743 & 3.38 & Cukup \\
\hline 5 & $\begin{array}{l}\text { Saya menggadaikan barang } \\
\text { karena ada kebutuhan yang } \\
\text { mendesak }\end{array}$ & 37 & 6 & 58 & 89 & 30 & 729 & 3.31 & \multirow[b]{2}{*}{ Cukup } \\
\hline \multirow[t]{2}{*}{6} & $\begin{array}{l}\text { Menurut saya, pembayaran } \\
\text { cicilan di Pegadaian Kantor } \\
\text { Wilayah VII Denpasar } \\
\text { sangat mudah dan bisa } \\
\text { membayar dengan cash atau } \\
\text { dengan transfer kartu kredit }\end{array}$ & 27 & 8 & 90 & 61 & 34 & 727 & 3.30 & \\
\hline & \multicolumn{6}{|c|}{ Rata-rata } & & 3,33 & Cukup \\
\hline
\end{tabular}

Sumber: Data Primer, 2020

Dilihat dari Tabel 4. menunjukkan bahwa variabel keputusan pembelian yang memiliki rata-rata terendah adalah pernyataan "Jika saya ingin menggadaikan barang saya pasti memilih jasa yang ditawarkan Pegadaian Kantor Wilayah VII Denpasar", diperoleh nilai rata-rata sebesar 3,28 yang masuk kriteria cukup, ini berarti secara umum responden jika ingin menggadaikan barang belum pasti memilih jasa yang ditawarkan Pegadaian Kantor Wilayah VII Denpasar.

Variabel keputusan pembelian yang memiliki rata-rata tertinggi adalah pernyataan "Saya memilih jasa Pegadaian Kantor Wilayah VII Denpasar karena merasa Aman", diperoleh nilai rata-rata sebesar 3,39 yang masuk kriteria baik, ini berarti secara umum responden memilih jasa Pegadaian Kantor Wilayah VII Denpasar karena merasa Aman. 
Tabel 5.

Deskripsi Jawaban Responden terhadap Digital Marketing

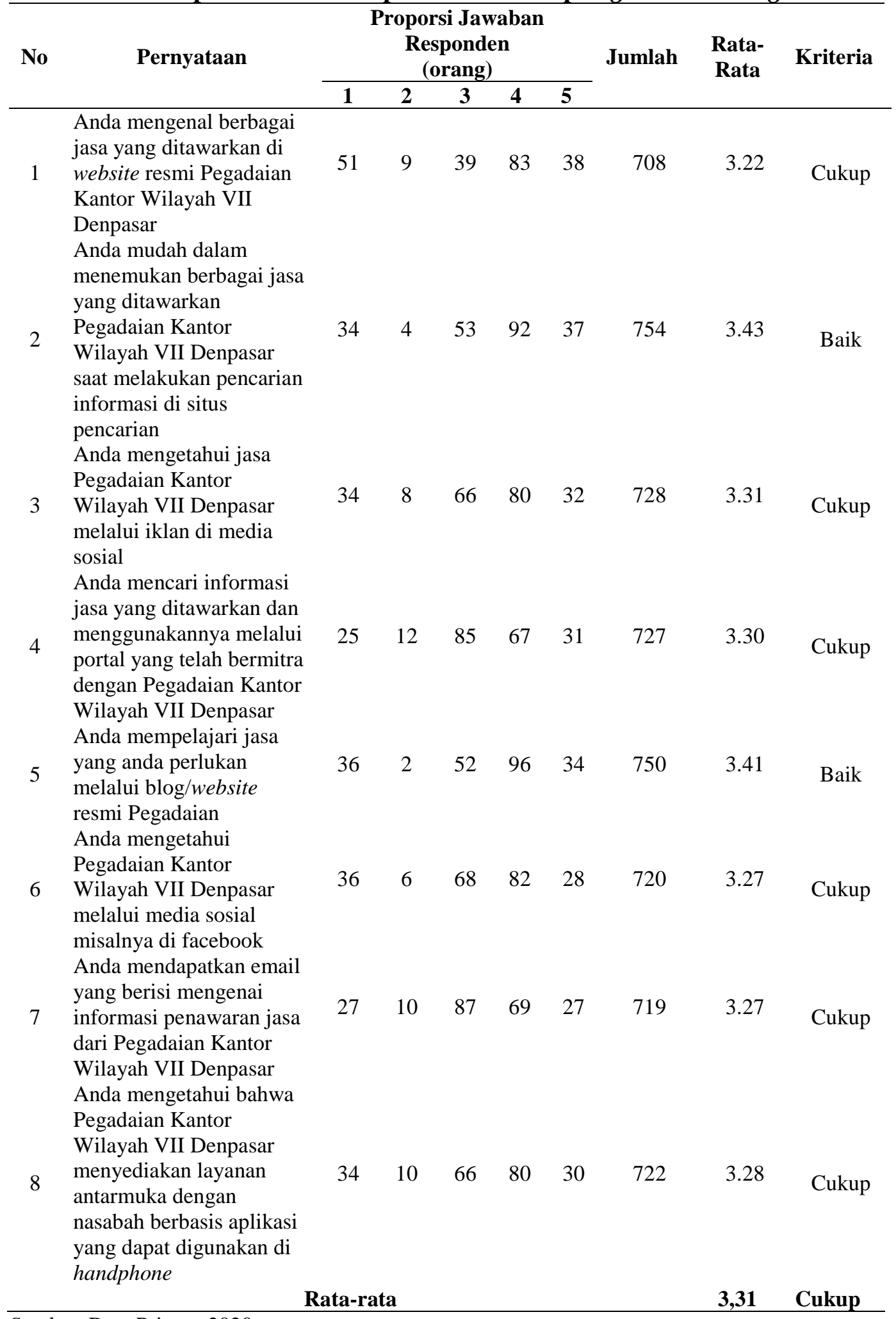

Sumber: Data Primer, 2020 
Variabel digital marketing pada penelitian ini merupakan variabel bebas. Variabel Digital Marketing yang disimbolkan dengan $\mathrm{X}_{1}$ serta diukur dengan menggunakan 8 pernyataan yang ditanggapi menggunakan 5 poin Skala Likert. Hasil penelitian responden terhadap variabel digital marketing dapat dilihat lebih rinci pada Tabel 5. diatas.

Berdasarkan Tabel 5. diketahui persepsi responden mengenai variabel Digital Marketing yang memiliki rata-rata tertinggi dan terendah adalah variabel Digital Marketing yang memiliki rata-rata terendah adalah pernyataan "Anda mengenal berbagai jasa yang ditawarkan di website resmi Pegadaian Kantor Wilayah VII Denpasar", diperoleh nilai rata-rata sebesar 3,22 yang masuk kriteria cukup, tetapi memiliki nilai rata-rata yang rendah dibandingkan dengan pernyataan yang lainnya ini berarti secara umum responden menganggap belum mengenal berbagai jasa yang ditawarkan di website resmi Pegadaian Kantor Wilayah VII Denpasar.

Variabel Digital Marketing yang memiliki rata-rata tertinggi adalah pernyataan "Anda mudah dalam menemukan berbagai jasa yang ditawarkan Pegadaian Kantor Wilayah VII Denpasar saat melakukan pencarian informasi di situs pencarian", diperoleh nilai rata-rata sebesar 3,43 yang masuk kriteria baik, ini berarti secara umum responden menganggap responden mudah dalam menemukan berbagai jasa yang ditawarkan Pegadaian Kantor Wilayah VII Denpasar saat melakukan pencarian informasi di situs pencarian.

Tabel 6.

Deskripsi Jawaban Responden terhadap Word of Mouth

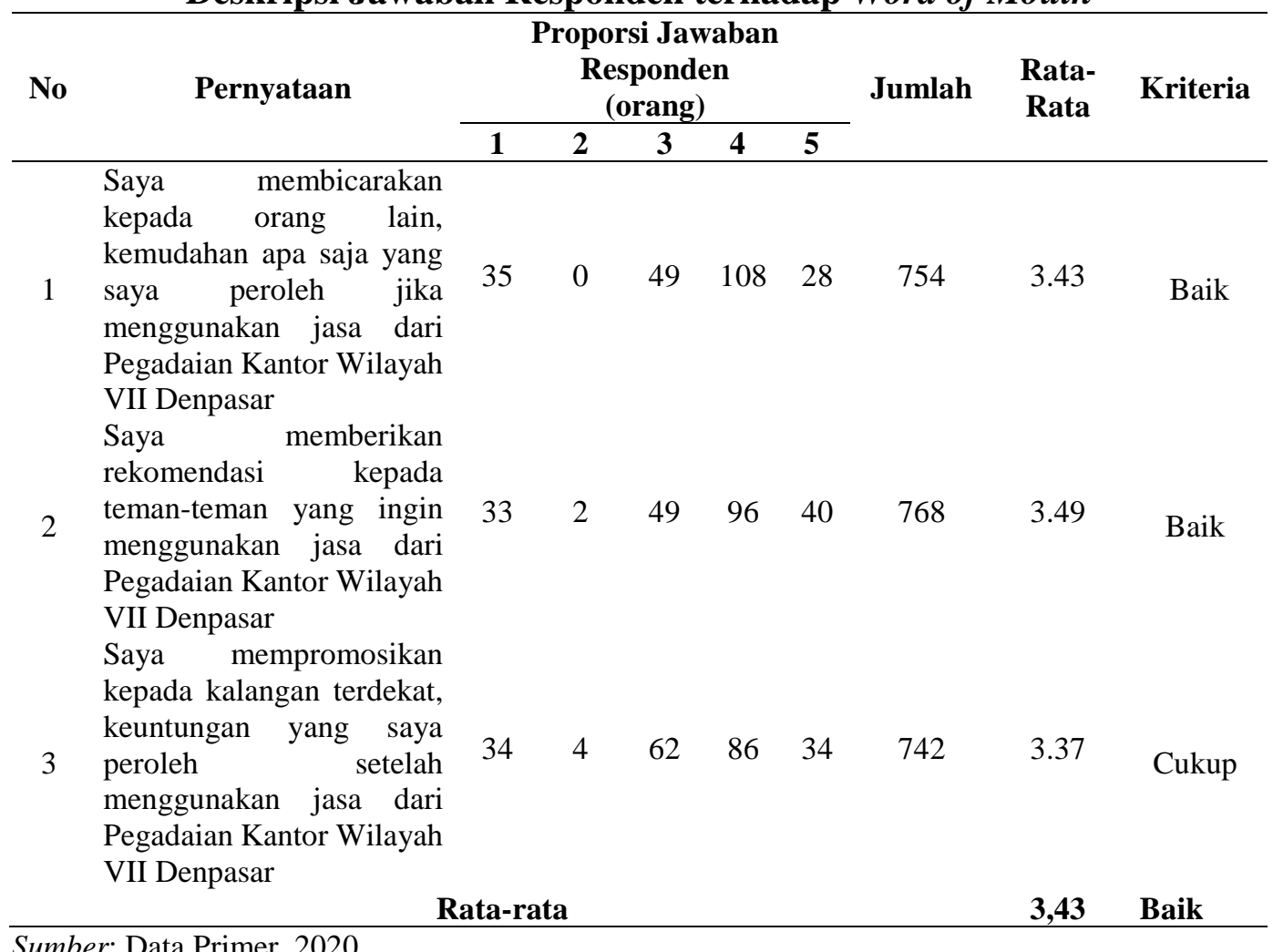


Variabel Word of Mouth pada penelitian ini merupakan variabel bebas. Variabel Word of Mouth yang disimbolkan dengan $\mathrm{X}_{2}$ serta diukur dengan menggunakan 3 pernyataan yang ditanggapi menggunakan 5 poin Skala Likert. Hasil penelitian responden terhadap variabel digital marketing dapat dilihat lebih rinci pada Tabel 6. diatas.

Berdasarkan Tabel 6. diketahui persepsi responden mengenai variabel Word of Mouth yang memiliki rata-rata tertinggi dan terendah adalah variabel Word of Mouth yang memiliki rata-rata terendah adalah pernyataan "Saya mempromosikan kepada kalangan terdekat, keuntungan yang saya peroleh setelah menggunakan jasa dari Pegadaian Kantor Wilayah VII Denpasar", diperoleh nilai rata-rata sebesar 3,37 yang masuk kriteria cukup, tetapi memiliki nilai rata-rata yang rendah dibandingkan dengan pernyataan yang lainnya ini berarti secara umum responden belum mempromosikan kepada kalangan terdekat, keuntungan yang mereka peroleh setelah menggunakan jasa dari Pegadaian Kantor Wilayah VII Denpasar.

Variabel Word of Mouth yang memiliki rata-rata tertinggi adalah pernyataan "Saya memberikan rekomendasi kepada teman-teman yang ingin menggunakan jasa dari Pegadaian Kantor Wilayah VII Denpasar", diperoleh nilai rata-rata sebesar 3,49 yang masuk kriteria baik, ini berarti secara umum responden memberikan rekomendasi kepada teman-teman yang ingin menggunakan jasa dari Pegadaian Kantor Wilayah VII Denpasar.

Variabel kualitas pelayanan pada penelitian ini merupakan variabel bebas. Variabel Kualitas Pelayanan yang disimbolkan dengan $X_{3}$ serta diukur dengan menggunakan 5 pernyataan yang ditanggapi menggunakan 5 poin Skala Likert. Hasil penelitian responden terhadap variabel digital marketing dapat dilihat lebih rinci pada Tabel 7 berikut.

Berdasarkan Tabel 7 diketahui persepsi responden mengenai variabel Kualitas Pelayanan yang memiliki rata-rata tertinggi dan terendah adalah sebagai berikut.

Variabel Kualitas Pelayanan yang memiliki rata-rata terendah adalah pernyataan "Perusahaan memberikan jaminan jika terjadi kendala dalam proses pengajuan di Pegadaian Kantor Wilayah VII Denpasar dan Penampilan karyawan administrasi sangat menarik (Kerapihan, kebersihan, seragam petugas)", diperoleh nilai rata-rata sebesar 3,25 yang masuk kriteria cukup, tetapi memiliki nilai ratarata yang rendah dibandingkan dengan pernyataan yang lainnya ini berarti secara umum Perusahaan belum memberikan jaminan jika terjadi kendala dalam proses pengajuan di Pegadaian Kantor Wilayah VII Denpasar dan Penampilan karyawan administrasi belum menarik (Kerapihan, kebersihan, seragam petugas).

Variabel Kualitas Pelayanan yang memiliki rata-rata tertinggi adalah pernyataan "Karyawan mampu memberikan masukan kepada nasabah dalam menggunakan jasa dari Pegadaian Kantor Wilayah VII Denpasar", diperoleh nilai rata-rata sebesar 3,39 yang masuk kriteria cukup, ini berarti secara umum responden memperhatikan Karyawan mampu memberikan masukan kepada nasabah dalam menggunakan jasa dari Pegadaian Kantor Wilayah VII Denpasar. 
Tabel 7.

Deskripsi Jawaban Responden terhadap Kualitas Pelayanan

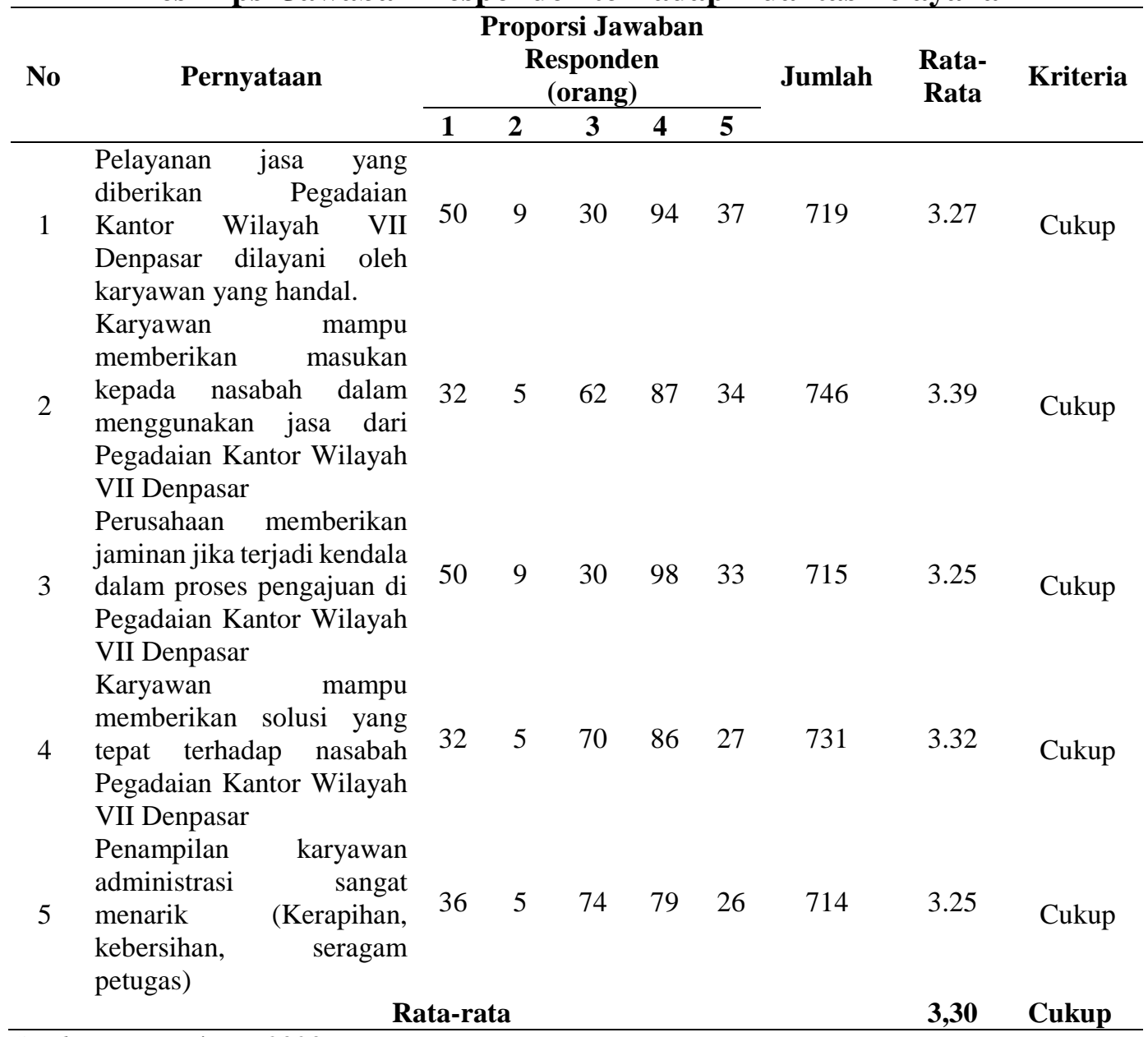

Sumber: Data Primer, 2020

Model analisis regresi linear berganda digunakan untuk mendapat koefisien regresi yang akan menentukan apakah hipotesis yang dibuat akan diterima atau ditolak. Hasil analisis ini mengacu pada hasil pengaruh variabel Digital Marketing $\left(\mathrm{X}_{1}\right)$, variabel Word of Mouth $\left(\mathrm{X}_{2}\right)$ variabel Kualitas Pelayanan $\left(\mathrm{X}_{3}\right)$ terhadap Keputusan Pembelian (Y) Pada PT. Pegadaian (Persero) Kantor Wilayah VII Denpasar. Adapun hasil analisis regresi dengan program (SPSS) versi 21.0 for Windows dapat dilihat pada Tabel 8. berikut. berikut.

Berdasarkan Tabel 8. dapat ditulis persamaan regresi linear berganda sebagai

$$
Y=-0,025+0,324 X_{1}+0,170 X_{2}+0,515 X_{3}
$$

Dimana :

$\mathrm{Y}=$ Keputusan Pembelian

$\mathrm{X}_{1}=$ Digital Marketing

$\mathrm{X}_{2}=$ Word of Mouth

$\mathrm{X}_{3}=$ Kualitas Pelayanan 
Tabel 8.

Rangkuman Hasil Analisis Regresi Linear Berganda

\begin{tabular}{|c|c|c|c|c|c|}
\hline \multirow{2}{*}{ Model } & \multicolumn{2}{|c|}{$\begin{array}{l}\text { Unstandardized } \\
\text { Coefficients }\end{array}$} & \multirow{2}{*}{$\begin{array}{c}\begin{array}{c}\text { Standardized } \\
\text { Coefficients }\end{array} \\
\text { Beta }\end{array}$} & \multirow[t]{2}{*}{$\mathbf{t}$} & \multirow[t]{2}{*}{ Sig. } \\
\hline & B & Std. Error & & & \\
\hline (Constant) & -0.025 & 0.103 & & -0.242 & 0.809 \\
\hline Digital Marketing & 0.324 & 00.049 & 0.305 & 6.624 & 0.000 \\
\hline Word of Mouth & 0.170 & 0.040 & 0.174 & 4.267 & 0.000 \\
\hline Kualitas Pelayanan & 0.515 & 0.045 & 0.520 & 11.484 & 0.000 \\
\hline
\end{tabular}

Nilai constant -0,025 menunjukan apabila Digital Marketing, Word of Mouth dan Kualitas Pelayanan bernilai sama dengan 0 (nol) maka Keputusan Pembelian Pada PT. Pegadaian (Persero) Kantor Wilayah VII Denpasar akan menurun. $\mathrm{X}_{1}=+0,324$ menunjukkan bahwa Digital Marketing berpengaruh positif terhadap Keputusan Pembelian Pada PT. Pegadaian (Persero) Kantor Wilayah VII Denpasar, apabila Digital Marketing meningkat maka Keputusan Pembelian akan mengalami peningkatan. $\mathrm{X}_{2}=+0,170$ menunjukkan bahwa Word of Mouth berpengaruh positif terhadap Keputusan Pembelian Pada PT. Pegadaian (Persero) Kantor Wilayah VII Denpasar, apabila Word of Mouth meningkat maka Keputusan Pembelian akan mengalami peningkatan. $\mathrm{X}_{3}=+0,515$, menunjukkan bahwa Kualitas Pelayanan berpengaruh positif terhadap Keputusan Pembelian Pada PT. Pegadaian (Persero) Kantor Wilayah VII Denpasar, apabila Kualitas Pelayanan karyawan meningkat maka Keputusan Pembelian akan mengalami peningkatan.

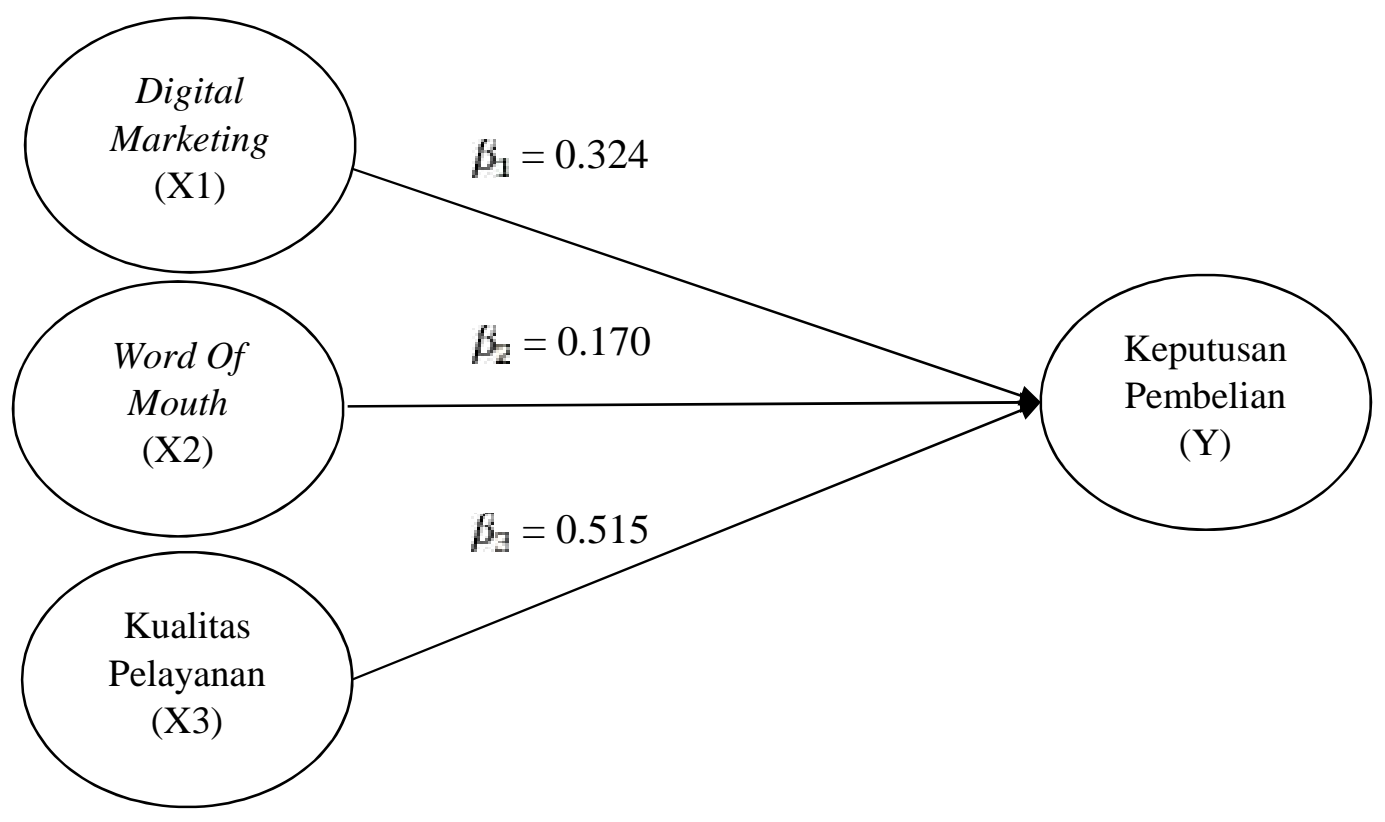

Gambar 1. Diagram Model Analisis Regresi Linear Berganda 
Pada penelitian ini pengujian normalitas dilakukan menggunakan analisis analisis statistik One-Sample Kolmogorov-Smirnov, yaitu dengan membandingkan Kolmogorov-Smirnov hitung dengan nilai signifikansi 0.05. One-Sample Kolmogorov-Smirnov pada uji non parametrik. Adapun hasil uji One-Sample Kolmogorov-Smirnov dapat ditampilkan dalam Tabel 9.

Tabel 9.

Uji Normalitas (One-Sample Kolmogorov-Smirnov)

\begin{tabular}{lr}
\hline & \multicolumn{2}{c}{ Unstandardized } \\
Residual
\end{tabular}

Berdasarkan uji normalitas dengan menggunakan One-Sample KolmogorovSmirnov Test yang ditampilkan pada Tabel 9. tersebut menunjukkan bahwa besarnya nilai Kolmogorov-Smirnov adalah sebesar 0,098. Nilai KolmogorovSmirnov tersebut lebih besar dibandingkan dengan nilai signifikansi sebesar 0,05 maka dapat ditarik kesimpulan bahwa data yang digunakan pada penelitian ini terdistribusi normal, sehingga dapat disimpulkan bahwa model memenuhi asumsi normalitas.

Uji multikolinearitas dilakukan untuk melihat apakah terdapat korelasi yang sempurna antar variabel bebas yang digunakan pada penelitian ini. Pengujian multikolinearitas dilakukan dengan menganalisis nilai tolerance dan nilai VIF. Nilai tolerance dan nilai VIF digunakan untuk mengukur variabilitas variabel independen atau hubungan antar variabel independen, jika nilai tolerance kurang dari 0,10 atau nilai VIF lebih dari 10 maka menunjukkan adanya multikolinearitas. Adapun nilai tolerance dan nilai VIF ditunjukkan pada Tabel 10. berikut:

Tabel 10.

Uji Multikolinieritas (Tolerance dan Variance Inflation Factor)

\begin{tabular}{llll}
\hline \multirow{2}{*}{\multicolumn{1}{c}{ Variabel }} & \multicolumn{3}{c}{ Collinearity Statistics } \\
\cline { 2 - 4 } & Tolerance & VIF \\
\hline Digital Marketing & & 0.329 & 3.035 \\
Word of Mouth & 0.418 & 2.394 \\
Kualitas Pelayanan & 0.340 & 2.937 \\
\hline
\end{tabular}

Sumber: Data Primer, 2020

Berdasarkan Tabel 10. tersebut ditunjukkan bahwa tidak terdapat variabel bebas yang memiliki nilai tolerance kurang dari 0,10 dan juga tidak ada variabel bebas yang memiliki nilai VIF lebih dari 10. Maka dari pada itu model regresi bebas dari gejala multikoleniaritas

Pengujian heteroskedastisitas diakukan melalui metode glesjer dan dengan grafik scatterplot. Metode glesjer meregresikan model regresi untuk mendapatkan nilai residualnya, kemudian nilai residual tersebut diabsolutkan dan dilakukan regresi dengan semua variabel independen. Bila terdapat variabel independen yang 
berpengaruh secara signifikan terhadap residual absolut maka terjadi heteroskedastisitas pada model regresi ini. Tabel 11. menunjukkan hasil perhitungan statistik dengan metode glesjer.

Tabel 11.

Uji Heteroskedastisitas (Uji Glesjer)

\begin{tabular}{|c|c|c|c|c|c|}
\hline \multirow{2}{*}{ Variabel } & \multicolumn{2}{|c|}{ Unstandardized Coefficients } & \multirow{2}{*}{$\begin{array}{c}\text { Standardized } \\
\text { Coefficients } \\
\text { Beta } \\
\end{array}$} & \multirow[t]{2}{*}{$\mathbf{t}$} & \multirow[t]{2}{*}{ Sig. } \\
\hline & B & Std. Error & & & \\
\hline (Constant) & 0.422 & 0.070 & & 6.009 & 0.000 \\
\hline $\begin{array}{l}\text { Digital } \\
\text { Marketing }\end{array}$ & -0.032 & 0.033 & -0.113 & -0.975 & 0.331 \\
\hline Word of Mouth & -0.016 & 0.027 & -0.059 & -0.575 & 0.566 \\
\hline $\begin{array}{l}\text { Kualitas } \\
\text { Pelayanan }\end{array}$ & -0.021 & 0.031 & -0.077 & -0.677 & 0.499 \\
\hline
\end{tabular}

Sumber: Data Primer, 2020

Berdasarkan Tabel 11. tersebut, ditunjukkan bahwa masing-masing model memiliki nilai signifikansi lebih besar dari 5\%. Hal ini menunjukkan bahwa variabel bebas yang digunakan pada penelitian ini tidak berpengaruh secara signifikan terhadap variabel terikatnya yaitu absolute error, maka dari itu, penelitian ini bebas dari gejala heteroskedastisitas.

Analisis derteminasi dilakukan untuk mengetahui sejauh mana variasi variabel bebas yaitu X1 (Digital Marketing), X2 (Word of Mouth) dan X3 (Kualitas Pelayanan) terhadap variabel Keputusan Pembelian (Y). Berdasarkan hasil spss yang dapat dilihat pada Tabel 12.

Tabel 12.

Analisis Determinasi

\begin{tabular}{lcrrr}
\hline Model & R Square & Adjusted R Square & $\begin{array}{c}\text { Std. Error of the } \\
\text { Estimate }\end{array}$ \\
\hline 1 & $0.922^{\mathrm{a}}$ & 0.849 & 0.847 & 0.45654 \\
\hline Sumber: Data Primer, 2020 & & & &
\end{tabular}

Berdasarkan Tabel 12. tersebut dapat diketahui bahwa nilai $r$ square $\left(\left(r^{2}\right)=\right.$ 0,849 Adapun analisis menggunakan rumus sebagai berikut:

$$
\begin{aligned}
& D=r^{2} \times 100 \% \ldots \ldots \\
& D=0,849 \times 100 \% \\
& D=84,9 \%
\end{aligned}
$$

Berdasarkan hasil tersebut diketahui bahwa nilai $\mathrm{R}^{2}=84,9$ persen, yang berarti bahwa sebesar 84,9 persen Keputusan Pembelian Pada PT. Pegadaian (Persero) Kantor Wilayah VII Denpasar dipengaruhi oleh variabel Digital Marketing (X1), Word of Mouth (X2), dan Kualitas Pelayanan (X3) dan sisanya sebesar 15,1 persen dipengaruhi oleh variabel lain yang tidak diteliti dalam penelitian ini.

Uji F digunakan untuk mengetahui apakah secara serempak (simultan) seluruh variabel bebas (variabel Digital Marketing, variabel Word of Mouth, dan variabel Kualitas Pelayanan), memiliki pengaruh terhadap variabel terikat 
(Keputusan Pembelian). Tabel 13. menunjukkan hasil perhitungan uji $\mathrm{F}$ dengan menggunakan SPSS 21.

Tabel 13.

Hasil Uji F

\begin{tabular}{rlrrrrr}
\hline Model & & Sum of Squares & df & Mean Square & \multicolumn{1}{c}{ F } & Sig. \\
\hline \multirow{2}{*}{1} & Regression & 253.600 & 3 & 84.533 & 405.579 & $0.000^{\mathrm{b}}$ \\
& Residual & 45.020 & 216 & 0.208 & & \\
& Total & 298.620 & 219 & & & \\
\hline
\end{tabular}

Sumber: Data Primer, 2020

Berdasarkan hasil analisis, diketahui nilai signifikansi $\mathrm{F}$ adalah $0,000<0,05$, maka $\mathrm{H}_{0}$ ditolak. Hal ini berarti bahwa variabel Digital Marketing $\left(\mathrm{X}_{1}\right)$, variabel Word of Mouth $\left(\mathrm{X}_{2}\right)$, variabel Kualitas Pelayanan $\left(\mathrm{X}_{3}\right)$, secara simultan berpengaruh signifikan terhadap Keputusan Pembelian (Y) Pada PT. Pegadaian (Persero) Kantor Wilayah VII Denpasar, atau model yang digunakan dalam penelitian layak dan dapat dipergunakan untuk analisis berikutnya.

Uji parsial (uji t) digunakan untuk menguji pengaruh masing-masing variabel bebas (variabel Digital Marketing, variabel Word of Mouth, variabel Kualitas Pelayanan) terhadap variabel terikat (Keputusan Pembelian). Tabel 14. menunjukkan hasil perhitungan uji t dengan menggunakan SPSS 21.

Tabel 14.

Hasil Uji t

Variabel

Digital Marketing

Word of Mouth

Kualitas Pelayanan

Sumber: Data Primer, 2020
Unstandardized Coefficients Beta Sig.

\begin{tabular}{ll}
0,324 & 0,000 \\
0,170 & 0,000 \\
0,515 & 0,000 \\
\hline
\end{tabular}

Berdasarkan pengolahan data SPSS dihasilkan tingkat signifikansi 0,000 < 0,05. Berdasarkan nilai pengujian tersebut, dapat dilihat dengan statistik bahwa uji jatuh pada penolakan $\mathrm{H}_{0}$ ditolak dan $\mathrm{H}_{\mathrm{a}}$ diterima untuk hipotesis pertama. Hal tersebut menyatakan penerimaan hipotesis yang bahwa terdapat pengaruh positif dan signifikan antara Digital Marketing terhadap Keputusan Pembelian Pada PT. Pegadaian (Persero) Kantor Wilayah VII Denpasar. Koefisien variabel X1 adalah positif 0,324 artinya Digital Marketing berpengaruh positif terhadap Keputusan Pembelian. Apabila Digital Marketing meningkat sedangkan Word of Mouth dan Kualitas Pelayanan tetap, maka Keputusan Pembelian akan meningkat. Hasil penelitian ini sesuai dengan penelitian yang dilakukan oleh Prasetya (2015) dalam penelitiannya pada pengaruh kegiatan Digital Marketing dan perilaku online konsumen pada peningkatan kesadaran konsumen dan dampaknya terhadap keputusan pembelian menemukan bahwa Digital Marketing berpengaruh positif terhadap keputusan pembelian. Penelitian yang dilakukan oleh Daria dan Setyorini (2017) menganalisi pengaruh strategi e-marketing mix kepada keputusan membeli pada toko online studi pada konsumen zalora.co.id Bandung. Hasil Secara parsial 
yang berpengaruh positif dan signifikan yaitu kemudahan penggunaan. Sedangkan yang berpengaruh negatif dan signifikan yaitu harga, produk, dan atmosfer website. Variabel yang tidak memiliki pengaruh yaitu kepercayaan dan promosi. Penelitian yang dilakukan oleh Fransilia (2020) meneliti tentang pengaruh Digital Marketing terhadap keputusan pembelian pada Matahari Departmen Store Manado Town Square. Hasil penelitian menunjukan bahwa hasil dari analisis regresi linear sederhana maka diperoleh nilai koefisien regresi yang positif, sehingga dapat dikatakan bahwa arah pengaruh variabel E-Commerce terhadap variabel keputusan pembelian yaitu positif.

Berdasarkan pengolahan data SPSS dihasilkan tingkat signifikansi $0,000<$ 0,05 . Berdasarkan nilai pengujian tersebut, dapat dilihat dengan statistik bahwa uji jatuh pada penolakan $\mathrm{H}_{0}$ ditolak dan $\mathrm{H}_{\mathrm{a}}$ diterima untuk hipotesis kedua. Hal tersebut menyatakan penerimaan hipotesis yang bahwa terdapat pengaruh positif dan signifikan antara terhadap Keputusan Pembelian Pada PT. Pegadaian (Persero) Kantor Wilayah VII Denpasar. Koefisien variabel X2 adalah positif 0,170, artinya Word of Mouth berpengaruh positif terhadap Keputusan Pembelian. Apabila Word of Mouth meningkat sedangkan Digital Marketing dan Kualitas Pelayanan tetap, maka Keputusan Pembelian akan meningkat. Hasil penelitian ini sesuai dengan penelitian yang dilakukan oleh Rangkuti (2010) Word Of Mouth adalah usaha memasarkan suatu produk atau jasa dengan menggunakan virus marketing sehingga pelanggan membicarakan, mempromosikan, dan merekomendasikan suatu produk dan jasa kepada orang lain secara antusias dan sukarela. Teknik ini sangat baik digunakan karena konsumen sebelum membeli barang dia akan mencari rekomendasi dari teman, kerabat atau keluarga terhadap pembelian produk. Kurnia (2015) melakukan penelitian dengan hasil bahwa komunikasi Word Of Mouth berpengaruh signifikan terhadap keputusan pembelian. Hal ini sejalan dengan penelitian yang dilakukan oleh Ibrahim \& Yuliati (2017) di Waroeng Steak and Shake Bandung yang menemukan bawha Word Of Mouth berpengaruh secara positif dan signifikan terhadap keputusan pembelian konsumen. Penelitian yang dilakukan oleh Rachman dan Totok (2016) meneliti tentang komunikasi Word of Mouth dan keputusan pembelian batik di Bangkalan. Hasil penelitian menyebutkan bahwa Faktor-faktor yang paling berpengaruh terhadap keputusan pembelian Batik Bangkalan adalah kesadaran merek dan resepsi masyarakat. Sedangkan faktor yang tidak berpengaruh terhadap keputusan pembelian adalah komunikasi Word Of Mouth. Tidak berpengaruhnya komunikasi Word Of Mouth terhadap keputusan pembelian Batik Bangkalan dikarenakan indikator yang digunakan variabel $\mathrm{X} 1$ hanya sebatas pada membicarakan, mempromosikan, dan merekomendasikan dan tidak sampai pada tahap mempersuasif, mengajak, dan mendorong masyarakat untuk membeli batik Bangkalan. Penelitian yang dilakukan oleh Rahmi (2017) meneliti tentang pengaruh Word Of Mouth Communication terhadap keputusan pembelian konsumen pada Boardgame Lounge Smart Cafe Pekanbaru.

Berdasarkan pengolahan data SPSS dihasilkan tingkat signifikansi $0,000<$ 0,05 . Berdasarkan nilai pengujian tersebut, dapat dilihat dengan statistik bahwa uji jatuh pada penolakan $\mathrm{H}_{0}$ ditolak dan $\mathrm{H}_{a}$ diterima untuk hipotesis ketiga. Hal tersebut menyatakan penerimaan hipotesis yang bahwa terdapat pengaruh positif dan 
signifikan terhadap Keputusan Pembelian Pada PT. Pegadaian (Persero) Kantor Wilayah VII Denpasar. Koefisien variabel X3 adalah positif 0,515, artinya Kualitas Pelayanan berpengaruh positif terhadap Keputusan Pembelian. Apabila Kualitas Pelayanan meningkat sedangkan Digita Marketing dan Word of Mouth tetap, maka Keputusan Pembelian akan meningkat. Hasil penelitian ini sesuai dengan penelitian yang dilakukan oleh Arifin (2017) dalam penelitiannya memiliki hasil bahwa kualitas pelayanan berpengaruh positif dan signifikan terhadap keputusan pembelian konsumen. Hal ini sejalan dengan penelitian Amrullah (2016) menemukan hubungan yang positif dan signifikan secara parsial antara variabel Kualitas Pelayanan dan variabel Keputusan Pembelian yang mengandung makna bahwa semakin tinggi kualitas pelayanan yang diberikan, maka konsumen cenderung untuk melakukan pembelian di perusahaan tersebut. Penelitian yang dilakukan oleh Febriano et al. (2018) meneliti tentang Analysis Of The Influencer Of Price, Promotion, Location And Service Quality On Purchase Decision In PT. Indomaret Manado Unit Jalan Sea. Hasil penelitian menunjukan bahwa Promosi berpengaruh positif dan tidak signifikan sedangkan Kualitas pelayanan berpengaruh negatif dan tidak signifikan terhadap keputusan pembelian konsumen. Harga, Promosi, Lokasi dan Kualitas Pelayanan secara simultan berpengaruh signifikan terhadap keputusan pembelian konsumen. PT. Indomaret Manado Unit Jalan Sea sebaiknya lebih meningkatkan strategi pemasaran dalam Harga, Promosi, Lokasi serta Kualitas Pelayanan untuk meningkatkan keputusan pembelian. Penelitian yang dilakukan oleh Hapzi Ali et al. (2018) meneliti tentang The Influence of Service Quality, Brand Image and Promotion on Purchase Decision at MCU Eka Hospital. Hasil penelitian menunjukan bahwa brand image, poromosi dan kualitas service memiliki pengaruh positif dan signifikan terhadap Purchasing decisions di Rumah Sakit MCU Eka.

Implkasi teoritis dari hasil penelitin ini memberikan bukti pada pengembangan ilmu perilaku Konsumen dan pemasaran khususnya mengenai Digital Marketing, Word of Mouth, Kualitas Pelayanan dan Keputusan Pembelian. Dengan demikian, hasil penelitian ini memberi dukungan empiris dan dapat dinyatakan memperkuat hasil-hasil studi terdahulu. Selain itu hasil penelitian ini secara praktis dapat menjadi salah satu acuan bagi peneliti lainnnya yang ingin meneliti mengenai Digital Marketing, Word of Mouth, Kualitas Pelayanan dan Keputusan Pembelian. Secara teoritis penelitian ini juga memberikan pemahaman bahwa Digital Marketing, Word of Mouth dan Kualitas Pelayanan secara nyata dapat meningkatkan Keputusan Pembelian dengan meningkatkan Digital Marketing, Word of Mouth dan Kualitas Pelayanan maka Keputusan Pembelian akan mengalami peningkatan.

\section{SIMPULAN}

Terdapat pengaruh positif dan signifikan antara Digital Marketing terhadap Keputusan Pembelian Pada PT. Pegadaian (Persero) Kantor Wilayah VII Denpasar. Hal ini berarti penggunaan Digital Marketing dapat meningkatkan Keputusan Pembelian. Terdapat pengaruh positif dan signifikan antara Word of Mouth terhadap Keputusan Pembelian Pada PT. Pegadaian (Persero) Kantor Wilayah VII 
Denpasar. Hal ini berarti penggunaan Word of Mouth dapat meningkatkan Keputusan Pembelian. Terdapat pengaruh positif dan signifikan antara Kualitas Pelayanan terhadap Keputusan Pembelian Pada PT. Pegadaian (Persero) Kantor Wilayah VII Denpasar. Hal ini berarti penggunaan Kualitas Pelayanan yang semakin baik dapat meningkatkan Keputusan Pembelian.

Berdasarkan keterbatasan yang terdapat dalam penelitian ini, maka penelti mengajukan saran bagi perusahaan yaitu pihak manajemen Pada PT. Pegadaian (Persero) Kantor Wilayah VII Denpasar harus lebih mengoptimalkan penggunaan Digital Marketing dalam memasarkan perusahaannya seperti mengupload konten yang menarik pada salah satu media sosial yang ada. Dari segi Word of Mouth perusahaan harus lebih mempromosikan kepada kalangan terdekatnya keuntangan apa yang didapat setelah menggunakan jasa dari PT. Pegadaian Kantor Wilayah VII Denpasar. Dari Kualitas Pelayanan harus tetap memberikan pelayanan yang sangat baik kepada konsumen atau nasabah agar para konsumen tersebut merasa nyaman dan puas. Bagi peneliti selanjutnya diharapkan pada peneliti selanjutnya tidak berpaku pada faktor-faktor dalam penelitian ini yaitu Digital Marketing dan Word of Mouth, namun dapat menambah faktor-faktor lain yang mungkin mempengaruhi Keputusan Pembelian. Peneliti selanjutnya diharapkan dapat menambahkan atau menggunakan subjek penelitian lain.

\section{REFERENSI}

A. Parasuraman, Valarie A. Zeithaml, and Leonard L. Berry. 1988. "SERVQUAL: A Multiple-Item Scale for Measuring Consumer Perceptions of Service Quality". Journal of Retailing. Vol 64 (1) pp 12-37

Adrian, Payne. 2008. The Essence of Service Marketing (Pemasaran Jasa). Jakarta: Salemba Empat.

Afrina Yasmin, Sadia Tasneem, Kaniz Fatema. 2015. Effectiveness of Digital Marketing in the Challenging Age.

Aldila, H.F., Anna F., dan Netti T. 2017. Daya Saing Bawang Merah di Wilayah Sentra Produksi di Indonesia. Jurnal Manajemen dan Agribisnis 14 (1): 4353.

Assauri, Sofyan. 2002. Manajemen Pemasaran, dasar, konsep, dan strategi. Cetakan Ketiga, Jakarta: CV. Rajawali

Alma, B. (2013). Manajemen Pemasaran dan Pemasaran Jasa. Bandung: Alfabeta.

Ali, Hapzi. et .all,. 2018. The Influence of Service Quality, Brand Image and Promotion on Purchase Decision at MCU Eka Hospital. Saudi Journal of Business and Management Studies (SJBMS). ISSN 2415-6671 (Online) 
Amrullah. (2016). Pengaruh Kualitas Produk Dan Kualitas Layanan Terhadap Keputusan Pembelian Sepeda Motor Honda. Jurnal Ekonomi Dan Manajemen ISSN Print 1907-3011, ISSN Online 2528-1127, 13(2), 99-118.

Arifin, M. Z., \& Azhari, P. (2017). Pengaruh Kualitas Pelayanan Terhadap Keputusan Pembelian Konsumen Di Alfamart Kota Palangka Raya. Jurnal Al Qardh, v(2), 116-123.

Babin, Barry J, et al. (2005). Modelling Consumer Satisfaction and Word-ofMouth: Restaurant Patronage in Korea. The Journal of Services Marketing; 2005;19,3. ABI/INFORM Global.

Basu Swastha.2002.Manajemen Pemasaran. Edisi Kedua. Cetakan Kedelapan. Jakarta: Penerbit Liberty

Belch, George E., Belch, Michael A. 2009. Advertising and Promotion : An Integrated Marketing Communication Perpective, 8th Edition. New York. McGraw-Hill Companies.

Brown, et al, 2005, Spreading The Word Through Investigating Antecedents Of Consumers PositiveWord Of Mouth Intentions and Behaviors in a Retailing Context, Journal Of Marketing Science Vol 33 no.2 p.122-138

Clinton, Febriano.dkk., 2018. Analisis Pengaruh Harga, Promosi, Lokasi Dan Kualitas Pelayanan Terhadap Keputusan Pembelian Pada Pt. Indomaret Manado Unit Jalan Sea. Fakultas Ekonomi dan Bisnis, Jurusan Manajemen Universitas Sam Ratulangi Manado, ISSN 2303-1174.

Dewi, N. N. K. A., \& Warmika, I. G. K. (2017). Pengaruh Internet Marketing, Brand Awareness, Dan Wom Communication Terhadap Keputusan Pembelian Produk Spa Bali Alus. E-Jurnal Manajemen Udayana, 6(10), 5580-5606.

Fadly, M. (2018). Pengaruh Word of Mouth Terhadap Keputusan Pembelian ( Studi pada Cafe Shelter 1 Coffee Jalan Jamin Ginting Medan ). Universitas Sumatera Utara.

Ghozali, 2014. Aplikasi analisis Multivariate dengan Program SPSS. Badan Penerbit UNDIP, Semarang.

Gumilang, P. (2014). Pengaruh Telemarketing dan Internet Marketing terhadap Keputusan Pembelian Konsumen English First. Jurnal Bakrie, 2(3), 1-10. 
Ibrahim, A., \& Yuliati, A. L. (2017). Pengaruh Word Of Mouth Terhadap Keputusan Pembelian (Studi Padakonsumen Waroeng Steak And Shake Jln. Banteng No. 14 Bandung). Jurnal Manajemen, 4(2), 1-7.

Harrison, L and Jean Walker, 2001, The Measurement of Word Of Mouth Communication and An Investigation of Service Quality and Customer Commitment as Potential Antecedents, Journal of Service Research, Vol 4 No 1 p.60-75.

Hermawan, Agus. 2012. Komunikasi Pemasaran. Jakarta. Erlangga

Janathanan, C., \& Nizar, N. (2013). Impact of Green Marketing on Consumer Purchase Intention. Mediterranean Journal of Social Sciences, 1(2), 1-12. https://doi.org/10.5901/mjss.2013.v4n11p650

Kertajaya, Hermawan. 2002. MarkPlus on Strategy: 12 Tahun Perjalanan MarkPlus \& Co Membangun Strategi Perusahaan. Jakarta: Gramedia Pustaka Utama.

Kotler, Philip; Armstrong, Garry, 2008. Prinsip-prinsip Pemasaran,Jilid 1, Erlangga, Jakarta.

Kotler, Philiph dan Gari Amstrong. 2001. Dasar-dasar Pemasaran. Edisi ke-9. Jilid 1. Jakarta: Indeks.

Kotler, P., \& Keller, K. L. (2012). Marketing Management 13. New Jersey: Pearson Prentice Hall, Inc.

Kotler, P., \& Keller, K. L. (2016). Marketing Management 15th Edition. Harlow: Pearson Education Limited.

Kurnia, M. (2015). Pengaruh Word of Mouth Communication Terhadap Keputusan Pembelian Konsumen UMKM Di Area Wisata Kuliner Badaan Kota Magelang. Jurnal Fakultas Ekonomi, 1(2), 1-12.

Kumar, E.K., Ramesh, A. \& Kasiviswanath, R., 2005, Hypoglicemic and Antihyperglicemic Effect of Gmelina asiatica Linn. In normal and in alloxan Induced Diabetic Rats, Andhra Pradesh, Departement of Pharmaceutical Sciences

Laksana, D., \& Dharmayanti, D. (2018). Pengaruh Digital Marketing Terhadap Organizational Performance Dengan Intellectual Capital Dan Perceived 
Quality Sebagai Variabel Intervening Pada Industri Hotel Bintang Lima Di Jawa Timur. Jurnal Manajemen Pemasaran,

Lovelock, C, dan John Wirtz, 2011. "Pemasaran J asa P erspektif edisi 7" . Jakarta : Erlangga.

Marsilina M., Fransilia. 2019. Pengaruh Digital Marketing Terhadap Keputusan Pembelian Pada Matahari Department Store Manado Town Square, Jurnal Administrasi Bisnis. Vol. 9. No. 1, 2019 (p-ISSN 2338-9605; e-2655-206X).

Mazuanda, D. (2018). Pengaruh Citra Merek Dan Harga Terhadap Keputusan Pembelian Konsumen Pada Distro Vearst Jeans Bandung (Survey pada pengunjung Distro Vearst Jeans Bandung). Jurnal Pasundan, 1(2), 1-20.

Nasution, 2002. Metode Research : Penelitian ilmiah, Jakarta, PT.Bumi Aksara

Pepita D, Luh dan Styorini, Retno. 2017. Pengaruh Strategi E-Marketing Mix Kepada Keputusan Membeli Pada Toko Online (Studi Pada Konsumen Zalora.Co.Id Di Bandung). Jurnal Administrasi Bisnis, Fakultas Komunikasi dan Bisnis, Universitas Telkom.

Permatasari, A. M. (2017). Pengaruh Perception of Green Product, Brand Personality dan Perceived Quality Terhadap Minat Beli (Studi Empiris yang Dilakukan PAda Konsumen Produk Naava Green Cabang Yogyakarta). Yogyakarta: Universitas Negeri Yogyakarta.

Phamendyta Aldaning Azaria, Srikandi Kumadji, dan Fransisca Yaningwati. 2014. Pengaruh Internet Marketing terhadap Pembentukan Word of Mouth dan Efektifitas Iklan dalam Meningkatkan Brand Awareness (Studi pada Follower Akun Twitter Pocari Sweat di Jejaring Sosial Twitter). Jurnal Administrasi Bisnis, Vol. 13 No. 1

Pradiani, T. (2017). Pengaruh Sistem Pemasaran Digital Marketing Terhadap Peningkatan Volume Penjualan Hasil. JIBEKA, 11(2), 46-53.

Prasetya, H. Y., \& Nurmahdi, A. (2015). Pengaruh Kegiatan Pemasaran Digital Dan Perilaku Online Konsumen Pada Peningkatan Kesadaran Konsumen Dan Dampaknya Terhadap Keputusan Pembelian Via Website. Jurnal Administrasi Bisnis, 1(1), 1-15.

Putra, D. N. E. (2015). Pengaruh Word of Mouth Terhadap Keputusan Pembelian pada Cafe Roti Gempol dan Kopi Anjis. E-Proceeding of Management, 2(1), 758-763. 
Rani Dhuhri dan Yossi Diantimala. 2018. The Influence Of Institutional Ownership, Individual Ownership, and Managerial Ownership Toward Dividend Payout Ratio at Non-Financial Companies Registered In Indonesia Stock Exchange in 2012-2106. International Journal Of Social Science and Economic Research, Vol. 3 (3), pp 786-801.

Rahmi Pratiwi, Yuli. 2017. Pengaruh Word Of Mouth Communication Terhadap Keputusan Pembelian Konsumen Pada Boardgame Lounge Smart Cafe Pekanbaru, Jurusan Ilmu Komunikasi Fakultas Ilmu Sosial dan Ilmu Politik Universitas Riau, Pekanbaru, JOM FISIP Volume 4 No. 1 - Februari 2017

Rachman, Raniawati dan Totok Wahyu A. 2016. Komunikasi Word Of Mouth Dan Keputusan Pembelian Batik Bangkalan, Program Studi Ilmu Komunikasi, FISIP Universitas Muhammadiyah Sidoarjo.

Rachman, R., \& Abadi, T. W. (2017). Komunikasi Word Of Mouth Dan Keputusan Pembelian Batik Bangkalan. Jurnal ASPIKOM, 3(2), 285-295.

Rangkuti, F. (2010). Spriritual Leadership in Business. Jakarta: PT. Gramedia Pustaka Utama.

Reandy, Trinanda (2013). Pengaruh penerapan Media Audio Visual Terhadap Peningkatan Keterampilan Smash dalam Permainan Bulu Tangkis Pada Siswa Kelas XI SMA PGII 2 Bandung."

Romaniuk, J. and Bogomolova, S. (2005). "Variation in brand trust scores". Journal of Targeting, Measurement and Analysis for Marketing, Vol. 13 No. 4, pp. 363-73

Sugiyono. (2014). Metode Penelitian Kuantitatif dan R\&D. Bandung:Alfabeta.

Sugiyono. (2017). Metode Penelitian Bisnis. Bandung: Alfabeta.

Sumarwan, U. (2014). Perilaku Konsumen: Teori dan Penerapannya dalam Pemasaran. Bogor: Ghalia Indonesia.

Supranto, J dan Nanda Limakrisna. Perilaku Konsumen \& Strategi Pemasaran; Untuk Memenangkan Persaingan Bisnis. Jakarta : Mitra Wacana Media, 2011.

Steffes, Erin M and Burgee, Lawrence E. (2008). Social Ties and Online Word Of Mouth. 
Gede Wisnu Saputra, Pengaruh Digital M arketing...

Townson University, Maryland, USA (www.emeraldinsight.com/1066-2243.htm)

Stemvelt, Robert C., 2004. (Diterjemahkan oleh Purwoko) Perception of Service Quality. Allyn and Bacon, Massachusetts.

Sweeney, J. And Soutar, G. 2001. "Consumer perceived value: the development of a multiple item scale". Journal of Retailing, Vol. 77, pp. 203-205

Tjiptono. 2001. Manajemen Pemasaran dan Analisa Perilaku Konsumen, Yogyakarta: BPFE.

Tjiptono. 2006. Manajemen Jasa, Yogyakarta: BPFE.

Vidya, M. (2013). Analisis Pengaruh Kualitas Pelayanan (Tangible, Reliability, Responsiveness, Assurance, Dan Emphaty) Terhadap Kepuasan Konsumen (Studi Pada Dealer Mitsubishi PT Bumen Redja Abadi Semarang). Jurnal Undip, 1(1), 1-10. 